\title{
A Conceptual Framework for Developing of Regional Innovation Ecosystems
}

\author{
By Iryna Pidorycheva ${ }^{1}$, Hanna Shevtsova $^{1}$, Valentina Antonyuk ${ }^{1}$, Nataliia Shvets ${ }^{2}$, \\ Hanna Pchelynska ${ }^{2}$
}

\begin{abstract}
The article highlights a conceptual framework for developing of regional innovation ecosystems at the NUTS 1 level. The authors' definition of the innovation ecosystem of the region has been given. The ranking of EU-27 NUTS 1 regions by R\&D intensity indicator allowed identifying most innovatively active regions and draw the conclusion about their concentration in three scienceintensive macro-clusters. The conceptual model of the regional innovation ecosystem of Ukraine has been suggested taking into account features of its current territorial division. The key dimensions of the model include the goal of the ecosystem, its actors, the environment and the system of internal and external interrelationship. Considering the specifics of regional governance in Ukraine, it was substantiated that it is advisable to use the existing network of regional research centres as institutional tools to support regional innovation ecosystems at NUTS 1 level. It is suggested to create special coordination centres, in particular, regional innovation councils at NUTS 2 level.
\end{abstract}

Keywords: innovation ecosystem, innovation process, region, economic area, NUTS, actor, stakeholder, institutional tool, European Union, Ukraine

\section{Introduction}

The 2030 Agenda for Sustainable Development (United Nations, 2015), adopted by UN members in 2015, contains 17 Sustainable Development Goals. Goal 9 is about building resilient infrastructure, promoting inclusive and sustainable industrialization and fostering innovation.

The inclusion of the goal to foster innovation reflects common understanding that in modern conditions, sustainable development is impossible without high-tech production and mass spread of innovation in all spheres of social life. For developing countries, innovative development is the most important condition for overcoming the gap with developed countries, significantly increasing the competitiveness of the economy and welfare, ensuring security and sovereignty of the state. In the framework of European integration processes to build up an innovatively developed country, regional innovation ecosystems (RIES) play an important role. Their formation should be carried out in accordance with the strategic goals and capabilities of the regions and using the European experience. In the context of Ukraine's integration into the research, education and innovation environment of the European Union $(\mathrm{EU})$, it is important to implement the EU framework concept for the formation and implementation of state innovation policy. The policy is aimed to develop innovation ecosystems with a wide range of stakeholders (High Level Group on Innovation Policy, 2014; Joint Research Centre, 
2017).

Europe has declared an ambitious goal: "to compete for global innovation leadership", for which it intends to develop its own innovative development model, based on 10 fundamental building blocks for the competitiveness of its innovation ecosystem: (1) pan-European approach, (2) corporate-start-up collaboration, (3) innovation funding, (4) enabled government and public institutions, (5) data access and protection, (6) entrepreneurial talent, (7) digital education, reskilling and upskilling, (8) gender diversity, (9) digital infrastructure and interoperability, (10) harmonized legislation and standards (World Economic Forum, 2019).

The EU policy to strengthen innovation competitiveness is a clear indication of the strategic importance of innovation in ensuring economic growth and improving people's lives. For Ukraine, this policy should serve as a guide in the development and implementation of its own measures for the development of the national and regional innovation ecosystems, taking into account fast and large-scale changes in the global environment.

One of the notable trends in the development of innovation processes is the strengthening of the influence of regional factors. The regional level plays an important role in stimulating the development of national economies. It is considered to be most suitable for innovation. The process of creating new knowledge is concentrated in the regions and there is an appropriate infrastructure for their further dissemination and application. Knowledge transfer is more effective at the regional level through direct communication among innovators as opposed to the use of long communication channels at the macro level. Thus, OECD experts note that in innovation processes the strongest interaction takes place in proximity, within a radius of approximately 200 kilometers (OECD, 2013).

Each region creates its own unique conditions for the emergence of innovations related to the level of social and economic development, the structure of the economy, efficiency of institutions, accumulated knowledge and competencies, cultural attitudes of the population. Taking into account these conditions it is impossible to create a unified model of innovation management. Regional and local governments will be able to effectively exercise their powers to support innovation, if they have certain autonomy, appropriate power and resources. This is possible if decentralization is carried out.

In Ukraine, decentralization reform was launched in 2014. It was aimed at shifting from centralized inefficient and unstable model of public administration to the transfer of power to local communities through optimal distribution of powers among different levels of government.

However, in the process of decentralization, such an important territorial level as economic areas, which unite several regions, was overlooked. Economic areas were not formed administratively, but arose in the course of historical, socio-economic and cultural development and represent large socio-economic and cultural areas, united by common geographical location, cultural and mental characteristics, similar natural resources and structure of the economy. It is the economic regions that correspond to the NUTS 1 level in the Nomenclature of Territorial Units for Statistics (NUTS), which is widely used in the European Union to implement flexible regional policies in the spheres of science, education and innovation. 
The choice of the European vector obliges and stimulates Ukraine to follow the path of implementation of European integration reforms, to adopt rules, norms and practices of the EU for effective integration into the European environment and the system of formal EU institutions.

In the context of decentralization and implementation of the Association Agreement between Ukraine and the European Union, each Ukrainian region must find its niche, both nationally and in the EU market, to develop regional innovation ecosystems independently or together with the neighbouring regions.

The objective of the article is to substantiate conceptual framework for developing of RIES at the level of economic areas of Ukraine (they should meet the requirements of the European classification NUTS 1). We believe that the formation and development of RIES should be focused on modern understanding of innovation processes and systems, regional entities, regional development strategies, based on such theoretical and methodological approaches as the concept of innovation ecosystem and the European approach to territorial division and regional policy.

\section{The Concept of Innovation Ecosystem}

Traditionally, the innovation system at the national or regional level is understood as a network of organizations and institutions in the public and private sectors of the economy (enterprises that carry out innovations, educational and research institutions, financial and advisory institutions, government agencies, etc.), the activities and relationships of which lead to innovation. By extension of this point, the concept of innovation ecosystem considers the innovation process as a more complex and interdependent activity. From its standpoint, the innovation ecosystem is a close and dynamic interaction of many participants in the innovation process on the basis of:

- collaboration, that is interactive networking in the process of cooperation, exchange of knowledge and resources;

- co-specialization, that is performance of various roles and functions in joint creation of new values;

- co-production, in which companies and organizations participate in various but complementary activities;

- co-evaluation, that is joint interdependent development in the process of various forms and directions of interaction among all participants of the ecosystem.

An important feature of ecosystems is their ability to self-organize and self-develop. If management of innovation systems is dominated by regulation through external control influences, the nature of the ecosystem implies the presence of mechanisms of internal self-organization, which allows it to better adapt to external fluctuations and generate internal impulses of transformation (Shevtsova, 2016). After all, when ecosystem members work together in a flexible and less rigid conditions typical of a traditional hierarchical governance structure, they are able to achieve impressive short- and longterm economic and social outcomes (Bramwell et al., 2012). This is one of the most important advantages of the ecosystem approach: understanding that innovation cannot be generated solely by "top-down" administrative orders, but rather by "bottom-up" initiatives born of self-organization mechanisms and the potential for synergies among 
key innovation actors.

The ecosystem approach puts above the formation of a networked nonlinear, open, dynamic innovation environment based mainly on horizontal communication among innovation participants with different functions and capabilities that are closely interdependent. In this interpretation, the innovation ecosystem has an open dynamic nature. It is subject to continuous change under the influence of new motivations of participants and new external conditions.

According to the results of the study, we identify several properties inherent in innovation ecosystems and modern innovation processes, namely: nonlinearity; stability; openness; networking; co-evaluation; co-specialization; joint creation of new values (coproduction); self development; the ability to evolve over time and in relation to the external environment; collaboration; combination of ideas, concepts, disciplines and cultures; freedom; involvement of a wide range of stakeholders.

Based on the analysis of publications on the problem, different formats of ecosystem functioning were identified: (1) ecosystems organized around a focus (central) firm (Moore, 1993; Iansiti, Levien, 2004; Teece, 2016; Autio, Thomas, 2014; Sarafin, 2019); (2) ecosystems as "structures" built around a focal value proposition (focus innovation) (Adner, Kapoor, 2010; Kapoor, Lee, 2013; Adner, Kapoor, 2016; Adner, 2017); (3) ecosystems as specific environments, arising at different levels - from local to global (Bramwell et al., 2012; Hwang, Horowitt, 2012; Rabelo et al., 2015; Smorodinskaya et al., 2017); (4) ecosystems as platforms around which stakeholder activities are organized (Ceccagnoli et al., 2012; Gawer, Cusumano, 2014; Cennamo, Santaló, 2013; McIntyre, Srinivasan, 2017).

In contrast to the traditional understanding of innovation systems, the concepts of which generally cover national, regional, sectoral and corporate levels, ecosystems are not bound by spatial boundaries and can be formed even virtually. The innovation ecosystem can be built at many levels of economic activity - from a single project to an enterprise, at the national, regional and global levels. However, the prevailing viewpoint is that collaboration among participants in innovation processes is most productive in specific areas and is associated with the factor of regionalization (localization) of innovation processes (United Nations, 2011; OECD, 2013; Ivanov et al., 2018).

\section{European Approach to Territorial Division and Regional Policy}

The development of innovation ecosystem in the European community is carried out at all levels of governance. Regional governance has a priority role. Current NUTS classification, dated of 2016 (now updated to current members as of 2020), divides economic territory of the EU into 92 regions at NUTS 1 level (population from 3 to 7 million people), 244 regions at NUTS 2 level (population from 800 thousand persons up to 3 million people), 1215 regions at NUTS 3 level (population from 150 to 800 thousand people) (Eurostat, 2018).

The NUTS classification serves several purposes: (1) to ensure the coherence of the EU regional statistics standards; (2) allows analyzing and comparing social and economic situation of the regions on the basis of comparable data; (3) serves as the basis for the EU regional policy development. Therefore, NUTS 1 level is used to analyze the 
problems of regions that are at a lower than national level, in particular to analyze the impact of economic integration on these regions. NUTS 2 level is the basis for the analysis of regional and national problems of the EU member states and is used by them to conduct regional policy. NUTS 3 level covers regions that are too small for a complex analysis and are used to analyze specific problems and take appropriate action.

The EU legislation that regulates funding of Cohesion policy presupposes that support for the European Structural and Investment Funds is based solely on the classification of NUTS 2 regions. To obtain funding from these funds, NUTS 2 regions are classified into less developed regions, transition regions and more developed regions. The allocation of resources from funds depends on this classification.

According to (European Commission, 2019) the most innovative NUTS 2 region in Europe is Zurich in Switzerland. Top-10 best innovative regions in the EU include Helsinki-Uusimaa (Finland), Stockholm (Sweden), Hovedstaden (Denmark), Berlin (Germany), Oberbayern (Germany), Västsverige (Sweden), Sydsverige (Sweden), Karlsruhe (Germany), Utrecht (Netherlands) and Tübingen (Germany). In total, the Innovation Leaders group includes 38 Europe's regions NUTS 2, including 1 province of Belgium, 2 regions of Denmark, 12 government regions of Germany, 4 provinces of the Netherlands, 3 large areas of Finland, 4 national areas of Sweden, 3 sub-regions of Great Britain, 2 regions of Norway, 7 regions of Switzerland.

To build the ranking of NUTS 1 regions in the EU, we focused on the indicator of R\&D intensity (Expenditures for R\&D - Gross domestic R\&D expenditures, expressed as a percentage of GDP), as in the strategy EUROPE 2020 (European Commission, 2010) it plays the role of one of key indicators. It was planned that by $20203 \%$ of the EU's GDP should be invested in R\&D.

The calculations used the baseline data for 2017 on R\&D intensity in the NUTS 1 regions of the EU, as well as the United Kingdom, Iceland, Norway and Switzerland. In the countries with population of less than 7 million people, NUTS 1 regions were adopted as identical to a country as a whole. The results of the ranking are presented in the Table.

Table: Ranking of EU-27 NUTS 1 regions by R\&D intensity

\begin{tabular}{|c|c|c|c|c|c|c|c|}
\hline \multirow[b]{2}{*}{ Rank } & \multirow[b]{2}{*}{$\begin{array}{l}\text { Region } \\
\text { NUTS } 1\end{array}$} & \multirow[b]{2}{*}{$\begin{array}{l}\text { NUTS } \\
\text { code }\end{array}$} & \multirow[b]{2}{*}{ Country } & \multirow[b]{2}{*}{$\begin{array}{l}\text { R\&D inten- } \\
\text { sity, } \%\end{array}$} & \multicolumn{3}{|c|}{ Most innovative sub-region } \\
\hline & & & & & $\begin{array}{c}\text { Region } \\
\text { NUTS } 2\end{array}$ & $\begin{array}{l}\text { NUTS } \\
\text { code }\end{array}$ & $\begin{array}{c}\text { R\&D } \\
\text { inten-sity } \\
\%\end{array}$ \\
\hline 1 & $\begin{array}{c}\text { Baden- } \\
\text { Württemberg }\end{array}$ & DE1 & Germany & 5.70 & Stuttgart & DE11 & 7.69 \\
\hline 2 & Sudosterreich & AT2 & Austria & 4.30 & Steiermark & AT22 & 4.88 \\
\hline 3 & Sodra Sverige & SE2 & Sweden & 3.71 & Västsverige & SE23 & 4.83 \\
\hline 4 & Ostra Sverige & SE1 & Sweden & 3.67 & Stockholm & SE11 & 3.75 \\
\hline 5 & Berlin & DE3 & Germany & 3.41 & Berlin & DE30 & 3.41 \\
\hline 6 & Niedersachsen & DE9 & Germany & 3.13 & Brounschweig & DE91 & 8.52 \\
\hline 7 & Bauern & DE2 & Germany & 3.12 & Oberbayern & DE21 & 4.03 \\
\hline 8 & Denmark & $\mathrm{DK} 0$ & Denmark & 3.05 & Hovedstaden & DK01 & 4.76 \\
\hline 9 & Hessen & DE7 & Germany & 2.93 & Darmstadt & DE71 & 3.27 \\
\hline 10 & Sud-Ouest & FR6 & France & $\begin{array}{c}2.92 \\
\text { (NUTS 2013) }\end{array}$ & Midi-Pyrenees & FR62 & 4.75 \\
\hline
\end{tabular}




\begin{tabular}{|c|c|c|c|c|c|c|c|}
\hline 11 & Ile de France & FR1 & France & $\begin{array}{c}2.90 \\
\text { (NUTS } 2013\end{array}$ & Ile de France & FR10 & $\begin{array}{c}2.90 \\
\text { (NUTS } \\
2013\end{array}$ \\
\hline 12 & VlaamsGewest & BE2 & Belgium & 2.86 & \multicolumn{3}{|c|}{ confidential } \\
\hline 13 & Sachsen & DED & Germany & 2.81 & Dresden & DED2 & 4.13 \\
\hline 14 & Ostosterreich & AT1 & Austria & 2.79 & Wien & AT13 & 3.60 \\
\hline 15 & Bremen & DE5 & Germany & 2.79 & Bremen & DE50 & 2.79 \\
\hline 16 & Westosterreich & AT3 & Austria & 2.75 & Oberosterreich & AT31 & 3.46 \\
\hline 17 & Manner-Suomi & FI1 & Finland & 2.75 & $\begin{array}{l}\text { Helsinki- } \\
\text { Uusimaa }\end{array}$ & FI1B & 3.48 \\
\hline 18 & Centre-Est & FR7 & France & $\begin{array}{c}2.70 \\
\text { (NUTS 2013) }\end{array}$ & Rhone-Alpes & FR71 & $\begin{array}{c}2.77 \\
\text { (NUTS } \\
2013 \\
\end{array}$ \\
\hline 19 & Zuid-Nederland & NL4 & Netherlands & 2.66 & Noord-Brabant & NL41 & 3.03 \\
\hline 20 & Region wallonne & BE3 & Belgium & 2.64 & \multicolumn{3}{|c|}{ confidential } \\
\hline 21 & Rheinland-Pfalz & DEB & Germany & 2.46 & $\begin{array}{c}\text { Rheinhessen- } \\
\text { Pfalz }\end{array}$ & DEB3 & 3.97 \\
\hline 22 & Mediterranie & FR8 & France & $\begin{array}{c}2.38 \\
\text { (NUTS 2013) }\end{array}$ & $\begin{array}{c}\text { Provence-Alpes- } \\
\text { Cote d'Azur }\end{array}$ & FR82 & $\begin{array}{c}2.49 \\
\text { (NUTS } \\
2013)\end{array}$ \\
\hline 23 & Thüringen & DEG & Germany & 2.21 & Thüringen & DEG0 & 2.21 \\
\hline 24 & Hamburg & DE6 & Germany & 2.16 & Hamburg & DE60 & 2.16 \\
\hline \multirow{4}{*}{$\begin{array}{l}\text { Extra } \\
\text { infor- } \\
\text { mation }\end{array}$} & East of England & $\mathrm{UKH}$ & $\begin{array}{c}\text { United } \\
\text { Kingdom }\end{array}$ & 3.33 & East Anglia & UKH1 & 4.68 \\
\hline & Switzerland & $\mathrm{CH} 0$ & Switzerland & 3.29 & \multicolumn{3}{|c|}{ no data } \\
\hline & Norway & NO0 & Norway & 2.48 & Trondelag & NO06 & 4.79 \\
\hline & South East & UKJ & $\begin{array}{l}\text { United } \\
\text { Kingdom }\end{array}$ & 2.21 & $\begin{array}{c}\text { Berkshire, } \\
\text { Buckinghamshire } \\
\text { and Oxfordshire }\end{array}$ & UKJ1 & 3.63 \\
\hline
\end{tabular}

Source: own elaboration based on Eurostat online data codes: (rd_e_gerdreg)

The threshold value for inclusion in the ranking was chosen $2.15 \%$ which is the average in the EU R\&D intensity. The ranking includes 10 (out of 16) federal states of Germany, all 3 group of states of Austria, 2 (out of 3) regions of Sweden, Denmark, 4 (out of 9) ZEAT zones of France, 2 (out of 3) regions of Belgium, Mainland Finland and 1 (out of 4) group of provinces of the Netherlands. There are also 2 (out of 9) regions of England, Switzerland and Norway.

The top 5 EU countries in terms of R\&D intensity are: Sweden (3.37\%), Germany (3.07\%), Austria (3.05\%), Denmark (3.05\%) and Finland (2.73\%). At the same time, it is already clear that by the end of 2020 the European Union will not be able to reach the target level of $3 \%$. For comparative analysis, it is also advisable to provide relevant data on other important players in the world economy: the United States $-2.78 \%$, China (excluding Hong Kong) - 2.15\%, South Korea - 4.29\%, Japan - 3.20\%.

The analysis of the ratio between most and least innovative regions within one country showed that the largest gap in the innovation activity of NUTS 1 regions is observed in Germany (3.75 times), Spain (3.43), Poland (3.25), France (3.21) and also in the UK (3.25 times). A small gap prevails in such innovative countries as Belgium (1.33 times) and Austria (1.57 times).

The results of the study show that the largest innovation activity and European 
innovation investments are concentrated in a quarter of NUTS 1 regions, which form three science-intensive macro-clusters: Scandinavian (Sweden - Denmark - Finland Norway), Great Britain - Belgium - the Netherlands, and Germany - Austria Switzerland - France. Such territorial concentration of R\&D implies common features of RIES and similar institutional mechanisms of their formation and development, which can be used to strengthen the innovation policy of less developed regions.

Having chosen the vector of European integration, Ukraine should take into account the EU's approach to the division of economic territory by types of regions, which, in addition to harmonizing regional statistics between Ukraine and the EU and ensuring comparability of data, will improve the content of economic zoning. Based on this, the territory of Ukraine should be represented as a system consisting of:

- at the NUTS 1 level - of economic regions, the areas of which are close in their socioeconomic parameters and differ in specific specialization in all-Ukrainian division of labour. In the conditions of displacement of population in Ukraine, they can unite from 3 to 7 million people. There are from 6 to 9 of such regions in Ukraine depending on the zoning methodology of different researchers. Each region unites several lower-level regional entities (NUTS 2) - oblasts. It should be noted that NUTS 1 regional entities do not have centralized administrative bodies and financial resources to implement general economic policy. However, the oblasts that are part of them, with interconnected infrastructure, similar economic structure and similar problems, could provide more dynamic development, including innovation through cooperation and pooling of resources;

- at the NUTS 2 level - of oblasts (regions), which are administrative regional entities formed to ensure public administration. The administrative units of this level include 24 oblasts, Kyiv, Crimea. In terms of population, they fully comply with the European classification of NUTS 2 regions. These regions form the basis of the administrative and territorial division of Ukraine. They have regional authorities, carry out strategic and current management of socio-economic and innovative development of territories. Under conditions of decentralization, their powers and resources are growing. Their role in the formation of RIES should be the main one, but in the conditions of open and interconnected innovation processes they are called to provide wide interregional interaction and cooperation of innovation actors to open opportunities for innovation ecosystems at the level of economic regions.

\section{Conceptual Model of the Regional Innovation Ecosystem of Ukraine}

To increase the innovation level of the national economy of Ukraine, it is important to form effective innovation ecosystems at the regional level, both within the administrative region (oblast) and within the economic area. This is due to the growing role of regions in the socio-economic and innovative development of countries, as well as significant transformations of innovation processes, which can most dynamically and effectively unfold at the regional level.

The increasing role of the regional factor of the innovation process is associated with the following factors of regionalization and localization (Andersson, Karlsson, 2004; Florida, 2004; United Nations, 2011; OECD, 2013): 
firstly, by strengthening regionalization processes. The process of globalization at the present stage is accompanied by two processes: on the one hand, strengthening of integration, transfer of some state functions to a higher hierarchical level to global and international-regional organizations; on the other hand, regionalization, expansion of independence of regional and local communities as a result of processes of deconcentration, decentralization and distribution of powers of state authorities. The process of European regionalization develops most successfully at the present stage. The Declaration on European Regionalization recognizes regional and local self-government as one of the priorities in the development of the EU. Regional self-government is based on the principles of subsidiarity, solidarity and complementarity, which ensure a more balanced and dynamic development of regions and countries. Due to decentralization reform, Ukraine is also on the path of giving greater economic independence to the regions. They get more opportunities and powers to ensure regional socio-economic development, including innovation;

secondly, there is a low level of efficiency of innovation development management at the state level due to significant differences in economic development of territories, inability to fully take into account regional potential and priorities of innovation development, attract available resources and ensure cooperation of all participants in the innovation process. This necessitates the separation of powers in the state innovation policy, when the strategic directions of innovation development are determined at the state level, and their practical implementation is carried out at the regional level, taking into account the needs of strategic development of territories;

thirdly, concentration of educational, intellectual and cultural resources needed for innovation in the regions (mainly in regional centres), as well as the availability of appropriate infrastructure. This is largely due to the processes of urbanization which leads to a high concentration of highly educated and skilled labour in cities, especially in metropolitan areas, metropolises, developed regional centers, which are centers of economic activity that offer better employment conditions. Already, more than half of the world's population lives in cities and metropolises, and it is expected that by 2030 its number will increase to 5 billion people. They play a key role in stimulating the innovative development of national economies, as cities and metropolises produce more than $80 \%$ of the world GDP. Cities create favorable socio-cultural environment, which attracts highly qualified workers not only with career prospects, but also better access to educational and cultural resources, developed social infrastructure and high living standards. The accumulation of human capital becomes the centre of gravity of economic activity and innovation. If in the XIX-XX centuries the main productions were created around sources of natural raw materials and transport routes, in the XXI century most effective innovative companies appear where active creative class of the population is concentrated;

fourthly, increasing the role of the regional (local) level in innovation processes due to the intensification of globalization of the world economy, its transition to a new phase of development - globalization 4.0, as well as the development of glocalization (globalization + localization) trends. Objective processes of globalization and international specialization determine the dispersion of various parts of the production process around the world, placing them where there are local competitive advantages. At 
the same time, natural resources lose their exclusive role as a competitive advantage, giving way to a highly skilled workforce, developed infrastructure and efficient institutions which become increasingly important. Regions, having such advantages, become direct participants in the international division of labour, attract foreign investment and have greater opportunities for innovation which is facilitated by rapid development of information and communication technologies.

The analysis of theoretical foundations of innovation ecosystems allows the authors to define regional innovation ecosystem as a system consisting of dynamic community of networked (non-hierarchical) organizations (actors) with different functions and roles, which are built into the institutional framework of the region, operate under the influence of business factors, regulatory and innovation policy environments, share common vision for sustainable advanced innovation development of the region and the country as a whole are open to collaboration with actors of other innovation ecosystems. RIES is an organic component of the national innovation ecosystem, which operates in the global environment with its international organizations and institutions and global network of relationships.

Figure 1 presents the authors' conceptual model of the regional innovation ecosystem of Ukraine. This model has four dimensions, which together determine configuration of the ecosystem and ensure its unity and integrity. The first dimension is the goal (intended purpose) of the ecosystem. In our opinion, the overall goal of RIES is to ensure sustainable innovation development of the region (economic area) as the basis for high standard of living of the population.

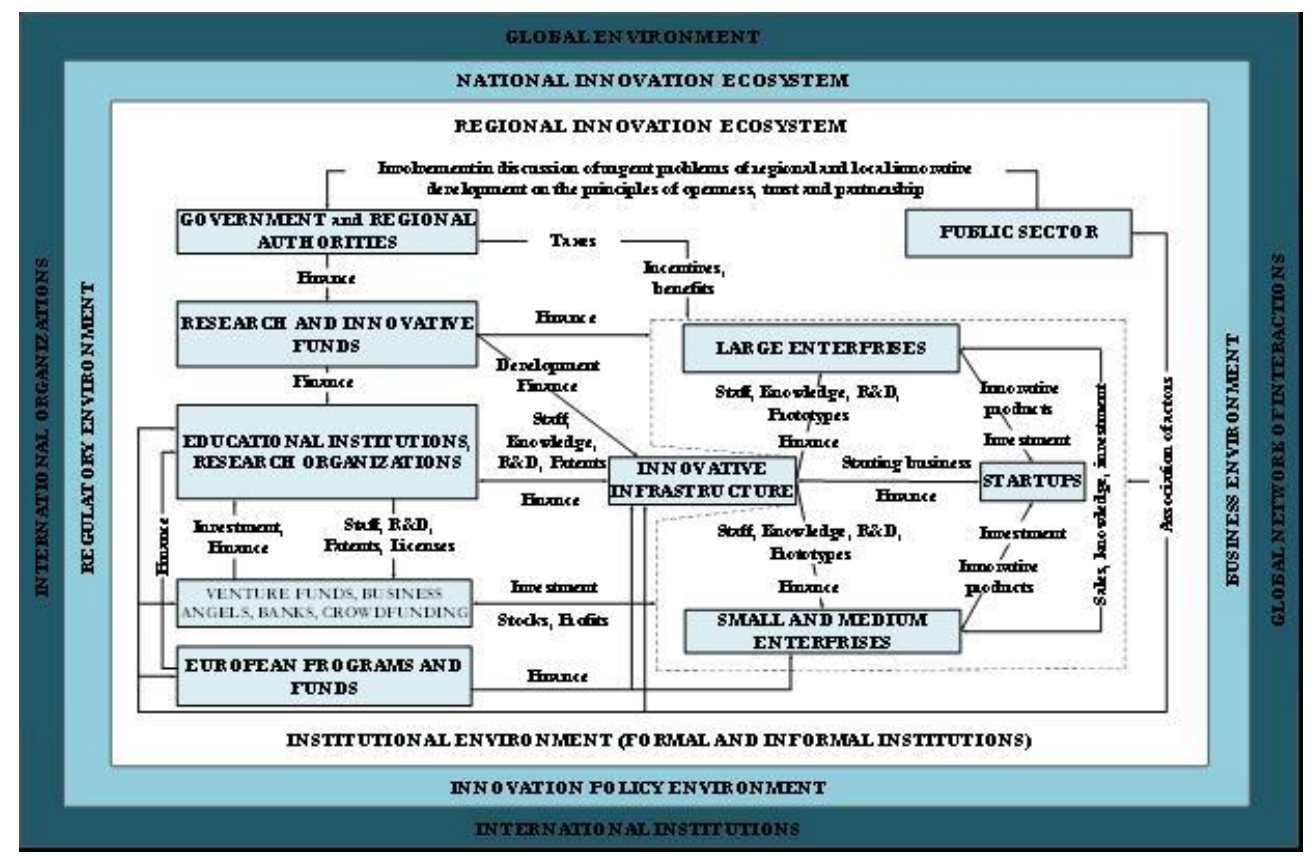

Figure 1: Conceptual model of the regional innovation ecosystem of Ukraine

Source: own elaboration 
The second dimension is the actors of the ecosystem that are considered as organizations embedded in the institutional structure of the region (economic area), represented by a set of institutions - official regulations and informal rules. Unlike traditional actors of the innovation ecosystem according to the Triple Helix model (academia/the university industry - government) or Quadruple Helix model (academia/the university - industry government - civil society), we propose to expand the list of actors in the innovation ecosystem, combining them in six groups (sectors), depending on their functions and roles:

- business sector, which creates innovative products (services) and forms the main demand for innovation;

- public sector, which promotes (supports) or blocks innovations;

- scientific and educational sector, which teaches, increases human potential; produces new knowledge, ideas, discoveries;

- financial security sector, which finances innovations during innovation cycle;

- infrastructure support sector, which connects actors in one location, performs incubation, testing, approbation, promotion on the market;

- sector of public associations, which provides and disseminates information, unites actors in solving common goals, adjusts goal-setting in socially significant areas.

The third dimension is the environment of organizations. This means the formation of innovation-friendly environment in business, regulatory and innovation policy environments; development of inclusive and blocking of extractive institutions (Acemoğlu, Robinson, 2014). Here we fully share the view (Hwang, Horowitt, 2012) that fortunate coincidence in the form of innovation cannot be designed by itself, but the environment that promotes fortunate coincidence can.

The fourth dimension is the system of relationships among actors within the ecosystem and with the external environment (national and global). For RIES to work, it is necessary not just to involve all necessary actors, but to ensure effective communication within one sector, different sectors and with the actors of other innovation ecosystems (regional, national, interstate and transboundary).

\section{Institutional Support of the Regional Innovation Ecosystem of Ukraine}

The formation and development of innovation ecosystem at the regional level requires coordination of the interests of many economic entities, which may or may not be linked by any business ties, and ensuring their real cooperation to achieve sustainable innovation in the region. Automatically, on the market basis, such collaboration cannot be ensured. It is necessary to coordinate these activities both by the state and the public by creating a single centre that has sufficient authority to do so.

In Ukraine, at the regional (oblast) level, there are state bodies of regional administration. However, most regional state administrations currently do not have a single body to ensure comprehensive innovative development of the territory, and such functions are scattered among different departments. For example, Dnipropetrovsk Regional State Administration has the Department of Economic Development, Department of Agroindustrial Development, Department of Education and Science, Department of Information Technologies and E-government, which to some extent take care of 
innovations. But none of them provides comprehensive innovative development of the region.

In Luhansk oblast, the Department of International Technical Assistance, Innovative Development and External Relations is tasked with substantiating the priority areas of regional innovation and development of regional innovation programmes, while the Department of Economic Development, Foreign Economic Activity and Tourism is responsible for working out projects of regional development strategies and plans of measures for their implementation.

At the same time, since 2019, Ukrainian regions have started implementation of the European approach to smart specialization and, in accordance with the new legal framework for the process of regional development strategy, should define areas of smart specialization. As shown by our experience of direct participation in the regional working group to develop a draft Development Strategy of Luhansk region for 20212027, the effectiveness of smart prioritization depends on the quality of entrepreneurial discovery process, introducing institutional tools for regular and transparent communications of all stakeholders (Shevtsova et al., 2020).

We believe that a special coordination centre should be established in the region on the basis of public-private partnership to develop and establish effective RIES activities. The centre would unite representatives of government, business, science, experts, recognized innovators and other actors of the innovation ecosystem. This may be a regional innovation council, which may carry out its activities under the regional state administration and have certain powers in the field of comprehensive innovative development of the territory. The priority tasks of such a body should be: setting up strategic priorities and operational tasks of innovative development of the territory; substantiation of recommendations for the development of local regulations and incentives for innovation; involvement of a wide range of stakeholders in interaction and cooperation; scientific and information support of the innovation process; establishing interregional and international partnerships to ensure innovative development.

At the level of economic area there are no administrative bodies. Regions belonging to a certain economic area, for the most part, independently carry out innovation activities without any cooperation. However, the integration of efforts and resources can provide a better innovation result, avoid the isolation of strategic planning and duplication of specializations, and help equalize development. Therefore, coordination of activities for the development of the ecosystem of the economic area can be carried out mainly on a voluntary basis with the involvement of leading actors in the innovation process of all regions that are part of the economic area. In our opinion, based on the leading role of science in ensuring innovative development, the functions of the main coordinator should be performed by regional research centres (RRCs).

There are six regional research centres in Ukraine, and five RRCs operate now. They are Donetsk RRC, Prydniprovskyi RRC, Southern RRC, Northeast RRC, and Western RRC (Lyashenko, Pidorycheva, 2017). However, Vinnytsia, Zhytomyr, Kyiv, Cherkasy and Chernihiv oblasts were not included in any of the research centres. Western RRC, which covers eight oblasts, artificially merged the Carpathian and Northwestern economic areas and broke Podillya economic area, two oblasts of which, Khmelnytskyi and Ternopil, became part of Western Research Centre, and the third, Vinnytsia oblast, remained 
outside them. In order for research centres to play a leading coordinating role in the development of innovation ecosystems of economic areas, it is proposed to unite Vinnytsia, Khmelnytskyi and Ternopil oblasts under the auspices of Podillya RRC of the National Academy of Science of Ukraine and Ministry of Education and Science of Ukraine. And Zhytomyr, Kyiv, Cherkasy and Chernihiv regions oblasts should be the part of Central Polissya RRC (Figure 2). The basis of these research centres can be scientific institutes of branch academies, in particular the National Academy of Agrarian Sciences, other scientific and educational institutions. Thus, the areas of RRC will generally coincide with the boundaries of economic areas and will correspond to the level of NUTS 1 of the European classification. Thus, the creation of RIES is due to the objective laws of development and complexity of scientific, technological and innovation processes, increasing regionalization and strengthening the role of regions in ensuring effective organization of economic and innovative activities. The functioning of RIES at both regional and economic levels will ensure a better use of regional resources and local initiative to enhance the intensity and effectiveness of innovation.

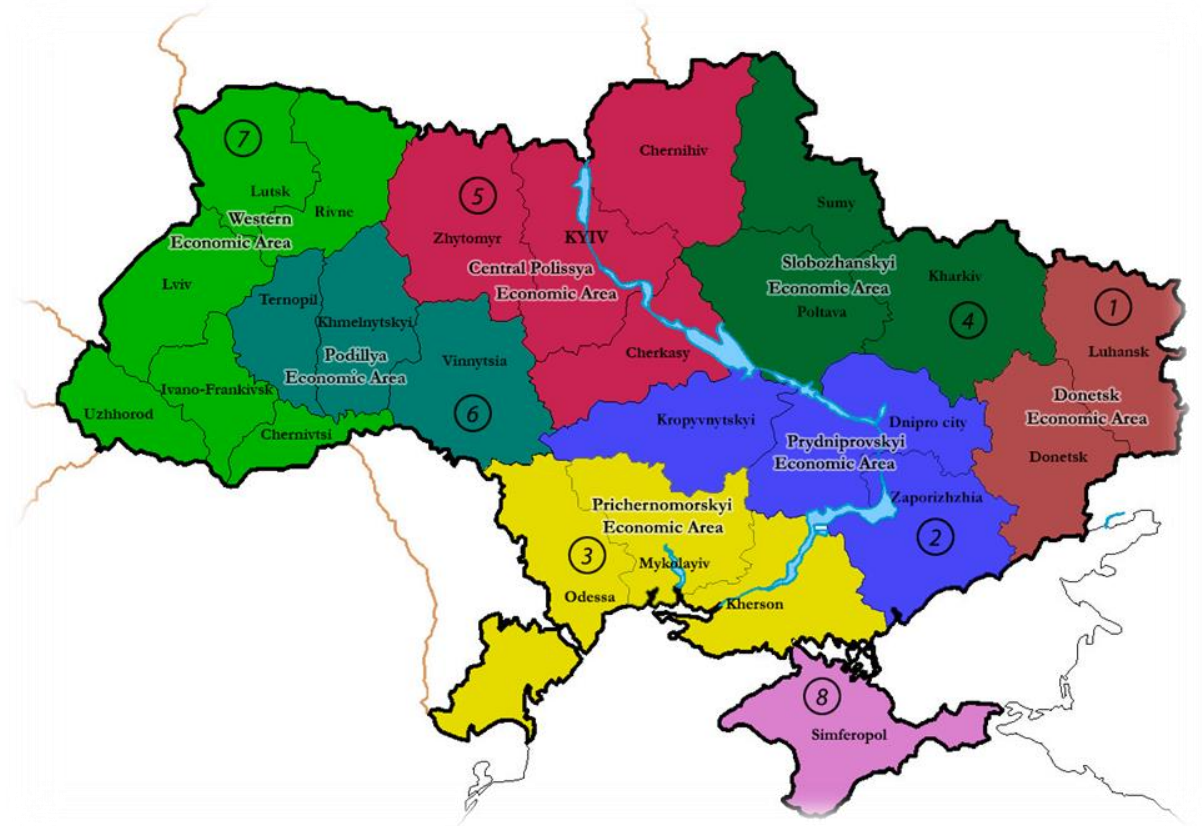

Figure 2: Map of economic areas of Ukraine according to the location of regional research centres of the National Academy of Sciences of Ukraine and Ministry of Education and Science of Ukraine, and the level of NUTS 1 EU

The map shows regional research centres in figures: (1) Donetsk Research Centre; (2) Prydniprovskyi Research Centre; (3) Southern Research Centre; (4) Northeast Research Centre; (5) Central Polissya Research Centre (suggested); (6) Podillya Research Centre (suggested); (7) Western Research Centre; (8) Crimean Research Centre.

Practical experience shows that the innovation ecosystem at the regional level will be effective only if the organizational core is created on the basis of public-private partnership, which unites interested in innovations and capable regional actors. There is 
established system of relationships and exchanges among its structural elements (actors), and it is open for the environment. The innovation ecosystem must be subject to continuous change under the influence of new motivations of participants and new external conditions of macroeconomic, technological and institutional nature, not only regional or national content, but also taking into account global perspective of fast and large-scale changes.

\section{Conclusion}

Modern innovation development largely depends on the innovation ecosystems of the regions, which are the areas of most intensive, dynamic and effective interaction among the participants of innovation processes. In the context of European integration processes, development of RIES in Ukraine should be carried out in accordance with the strategic objectives and potential of the regions, using European experience.

The article presents a conceptual approach to the formation of RIES, which is based on the concept of innovation ecosystem and European approach to territorial division and regional policy. The interpretation of the innovation ecosystem emphasizes the importance of collaboration, co-specialization, co-production and co-evaluation, which provide flexible dynamic interaction of actors in the innovation process on the basis of self-organization. The authors' definition of the regional innovation ecosystem emphasizes the openness of cooperation, network nature of relations, influence of factors of business, regulatory and innovation policy environments and the need for the common vision of regional innovation policy.

Regions NUTS 1 (level of economic area of Ukraine) and NUTS 2 (level of the region (oblast) of Ukraine) are considered in the context of tasks of management of innovation processes. The rating assessment of the EU-27 NUTS 1 regions according to R\&D intensity indicator allowed identifying most innovatively active regions, which are concentrated in three science-intensive macro-clusters. It is the features of their RIES and institutional support mechanisms that should be the subject of further case studies to strengthen the innovation policy of less developed regions and countries.

The proposed conceptual model of the regional innovation ecosystem of Ukraine has four key dimensions (the goal of the ecosystem, its actors, the environment and the system of relationships) and focuses on six groups(sectors) of actors (business, government, research, finance, infrastructure and society). An important component of RIES governance should be their institutional support.

We argue that existing regional research centres can act as coordination mechanisms in the innovation systems of NUTS 1 regions, and at NUTS 2 level the coordination of interests of many stakeholders and the organization of their cooperation can be carried out by specially created coordination centres, such as regional innovation councils.

Practical implementation of the proposed conceptual framework for the creation of RIES will improve the processes of strategic planning of regional innovative development, involve a wide range of stakeholders, intensify regional innovation initiatives and projects, and create institutional conditions to ensure sustainable innovation development of the regions and the country as a whole. 


\section{References}

Acemoğlu, D. \& Robinson J. A. (2012). Why Nations Fail: The Origins of Power, Prosperity and Poverty. New York: Crown.

Adner, R. (2017). Ecosystem as Structure. An Actionable Construct for Strategy. Journal of Management, 43 (1), 39-58. doi: 10.1177/0149206316678451.

Adner, R. \& Kapoor, R. (2010). Value Creation in Innovation Ecosystems: How the Structure of Technological Interdependence Affects Firm Performance in New Technology Generations. Strategic Management Journal, 31 (3), 306-333. doi: 10.1002/smj.821.

Adner, R. \& Kapoor, R. (2016). Innovation Ecosystems and the Pace of Substitution: Re-Examining Technology S-Curves. Strategic Management Journal, 37 (4), 625-648. doi: 10.1002/smj.2363.

Andersson, M. \& Karlsson, C. (2004). Regional Innovation Systems in Small \& Medium-Sized Regions: A Critical Review \& Assessment. In B. Johansson, C. Karlsson, R. Stough (Eds.), The Emerging Digital Economy: Entrepreneurship, Clusters and Policy, Springer-Verlag, Berlin, 55-81. doi: 10.1007/3-540-34488-8_4.

Autio, E. \& Thomas L. D. W. (2014). Innovation Ecosystems: Implications for Innovation Management? In M. Dodgson, D. M. Gann, N. Phillips (Eds.), The Oxford Handbook of Innovation Management. Oxford University Press, Oxford, 204-228. doi: 10.1093/oxfordhb/9780199694945.001.0001.

Bramwell, A., Hepburn, N., Wolfe, D. A. (2012). Growing Innovation Ecosystems: University-Industry Knowledge Transfer and Regional Economic Development in Canada. Final Report to the Social Sciences and Humanities Research Council of Canada.

Ceccagnoli, M., Forman, C., Huang, P., Wu, D. J. (2012). Co-Creation of Value in a Platform Ecosystem: The Case of Enterprise Software. MIS Quarterly, 36 (1), 263-290. doi: 10.2307/41410417.

Cennamo, C. \&Santaló, J. (2013). Platform Competition: Strategic Trade-Offs in Platform Markets. Strategic Management Journal. 34 (11), 1331-1350. doi: 10.1002/smj.2066.

European Commission. (2010). Europe 2020: A Strategy for Smart, Sustainable and Inclusive Growth. Brussels. COM(2010)2020. Retrieved from: https://ec.europa.eu/eu2020/pdf/COMPLET\%20 EN\%20BARROSO $\% 20 \% 20 \% 20007 \% 20-\% 20$ Europe $\% 202020 \% 20-\% 20$ EN\%20version.pdf.

European Commission. (2019). Regional Innovation Scoreboard 2019. Luxembourg: Publications Office of the European Union. doi:10.2873/89165.

Eurostat. (2018). Regions in the European Union - Nomenclature of Territorial Units for Statistics - NUTS 2016/EU-28. Luxembourg: Publications Office of the European Union. doi: 10.2785/475524.

Florida, R. (2003). Cities and the Creative Class. City \& Community, 2 (1), 3-19. doi: 10.1111/15406040.00034 .

Gawer, A. \& Cusumano, M. A. (2014). Industry Platforms and Ecosystem Innovation. Journal of Product Innovation Management, 31 (3), 417-433. doi: 10.1111/jpim.12105.

High Level Group on Innovation Policy. (2014). Inspiring and Completing European Innovation Ecosystems: The Way Forward to Improve People's Lives. Blueprint. Brussels: HLG Secretariat. Retrieved from: https://ec.europa.eu/futurium/en/system/files/ged/47-_hlg_reportinspiringcompletingeuinnoecosystem-2014_toconnected.pdf.

Hwang, V. \& Horowitt, G. (2012). The Rainforest: The Secret to Building the Next Silicon Valley. CreateSpace Independent Publishing Platform.

Iansiti, M. \& Levien R. (2004). Strategy as Ecology. Harvard Business Review, 82 (3), 68-78.

Ivanov, S., Lyashenko, V., Pidorycheva, I. et al. (2018). Ukrajina v jevropejsjkomunaukovo-osvitnjomu ta innovacijnomuprostori: koncepcijaadaptaciji ta integhraciji $\mathrm{v}$ umovakhUghody pro asociaciju $\mathrm{z}$ JevropejsjkymSojuzom. Kyiv: Institute of Industrial Economics.

Joint Research Centre. (2017). Current Challenges in Fostering the European Innovation Ecosystem. Luxembourg: Publications Office of the European Union. JRC108368. doi: 10.2760/768124.

Kapoor, R. \& Lee, J. M. (2013). Coordinating and Competing in Ecosystems: How Organizational Forms Shape New Technology Investments. Strategic Management Journal, 34 (3), 274-296. doi: 10.1002/smj.2010.

Lyashenko, V. \& Pidorycheva, I. (2017). Regional Science Centers under NAS and MES of Ukraine as the Core of the Development of Regional Innovation Systems in the Context of Decentralization. Economic Herald of the Donbas, 1 (47), 13-20. 
McIntyre, D. P. \& Srinivasan, A. (2017). Networks, Platforms, and Strategy: Emerging Views and Next Steps. Strategic Management Journal. 38 (1), 141-160. doi: 10.1002/smj.2596.

Moore, J. F. (1993). Predators and Prey: A New Ecology of Competition. Harvard Business Review, 71 (3), $75-86$.

OECD. (2013). Regions and Innovation: Collaborating across Borders. OECD Reviews of Regional Innovation. Paris: OECD Publishing. doi: 10.1787/9789264205307-en.

Rabelo, R. J., Bernus, P., Romero, D. (2015) Innovation Ecosystems: A Collaborative Networks Perspective. In Camarinha-Matos L., Bénaben F., Picard W. (Eds.) Risks and Resilience of Collaborative Networks. PROVE 2015. IFIP Advances in Information and Communication Technology, 463, Springer, Cham. doi: 10.1007/978-3-319-24141-8_29.

Sarafin, G. (2019). How an Ecosystem Forward Strategy Can Create Unique Customer Value. Retrieved from: https://www.linkedin.com/pulse/how-ecosystem-forward-strategy-can-create-unique-customer-sarafin.

Shevtsova, H. (2016). Synerghetychnyjmenedzhmentpidpryjemstv. Kyiv: Institute of Industrial Economics.

Shevtsova, H., Shvets, N., Kramchaninova, M., Pchelynska, H. (2020). In Search of Smart Specialization to Ensure the Sustainable Development of the Post-Conflict Territory: the Case of the Luhansk Region in Ukraine. European Journal of Sustainable Development, 9 (2), 512-524. doi: 10.14207/ejsd.2020.v9n2p512.

Smorodinskaya, N., Russell, M., Katukov, D., Still, K. (2017). Innovation Ecosystems vs. Innovation Systems in Terms of Collaboration and Co-creation of Value. Proceedings of the 50th Hawaii International Conference on System Sciences, 5245-5254. doi: 10.24251/HICSS.2017.636.

Teece, D. J. (2016). Business ecosystems. In Augier M., Teece D. J. (Eds.). Palgrave Encyclopedia of Management. Palgrave Macmillan UK. doi: 10.1057/978-1-349-94848-2_724-1.

United Nations. (2011). The Economic Role of Cities. United Nations Human Settlements Programme. The Global Urban Economic Dialogue Series, Nairobi.

United Nations. (2015). Transforming Our World: The 2030 Agenda for Sustainable Development. General Assembly of the United Nations. Retrieved from: https://www.un.org/ga/search/view_doc.asp ?symbol=A/RES/70/1\&Lang=E.

World Economic Forum. (2019). Innovate Europe Competing for Global Innovation Leadership. Retrieved from: http://www3.weforum.org/docs/WEF_Innovate_Europe_Report_2019.pdf. 